\title{
An Approach to the Stories of Sabahattin Ali within the Context of Marxist Literary Aesthetics: The Conflict between Peasants and the Intelligentsia
}

\author{
Murat Yigit ${ }^{1}$ \\ ${ }^{1}$ Turkish Education Department, Faculty of Education, Kirikkale University, Kirikkale, Turkey \\ Correspondence: Murat Yigit, Turkish Education Department, Faculty of Education, Kirikkale University, \\ 71450, Kirikkale, Turkey. Tel: 90-505-590-7265. E-mail: muratyigit06@gmail.com
}

Received: June 27, 2016

doi:10.5539/jel.v5n4p278
Accepted: July 31, 2016

Online Published: Ocober 30, 2016

\begin{abstract}
This study will try to read the stories of Sabahattin Ali, who has written various books in Turkish, within the context of Marxist literary aesthetics, assess the types and characters in the stories of Sabahattin Ali within that framework, and observe the social levels and the gaps between them based on the relationships between the two extreme poles (the peasants and the intelligentsia), which constitute the main theme of the author's works.

Many "socialist realist" authors/poets write within the context of Marxist literary aesthetics, although its era of major literary influence is now over. Nevertheless, although characters created in literary works with the purpose of disseminating ideologies are generally designed in line with the authors' intentions, are governed by them and are often not realistic or true-to-life, we can observe certain aspects that are in accord with these kinds of literary aesthetics while reading the adventures of Sabahattin Ali.
\end{abstract}

Keywords: marxist literary aesthetics, republic period of Turkish literature, conflict of peasants vs intelligentsia, Sabahattin Ali

\section{Introduction}

While the Turkish dictionary defines the intelligentsia as "cultured, literate, foresighted and enlightened individuals", the Oxford Advanced Learners dictionary defines them as leading individuals who perceive and interpret events in a rational way. A society expects its intelligentsia to view the problems of its society from a holistic perspective and seek solutions by categorizing these problems.

According to Edward Said, the intelligentsia should display the following attitudes and features:

The intelligentsia comprises individuals who have the ability to express a message, a view, an attitude or an opinion for and on behalf of a certain community. This role has a special and privileged aspect and it exists to represent problems that put annoying questions on the agenda of the community, object to dogmas instead of producing them, reject being dominated by governments or large companies and that are constantly forgotten or made forgotten (Said, 1994, p. 27).

Edward Said's definition of intelligentsia is the total opposite of the intelligentsia encountered in the stories of Sabahattin Ali. Said's intelligentsia generally embrace the problems of the times without merging with the political or economic system, criticize the irregularities in social institutions, understand the simple truth behind the visible world and object to the impositions of the existing system.

According to the Finnish intellectual John Wilhelm Snelman:

Being an intellectual does not mean wearing fashionable clothes, hats and starched shirts. The intelligentsia is the brain of the public. Our people have not put you in that position so that you can have a high income and a lot of fun at night after a good education. Such people cannot be a part of the real intelligentsia. They are just corrupt. All educated individuals are obliged to develop the national thought, awaken the national spirit and strengthen the national will (Petrov, 1998, p. 41).

In the stories of Sabahattin Ali, the intelligentsia are portrayed as incoherent and corrupt characters who insult peasants, ignore problems, offer imaginary suggestions, cut themselves off from the public and plan out their 
future in their cushy professions. They are also portrayed as self-seeking characters who waste the opportunities and aid given by the government to people and manipulate these opportunities for their own benefits/goals without considering the future of society. On the other hand, Ali portrays peasants as individuals dealing with problems such as long years of negligence, tax obligations, the struggle to earn a living, drought and deprivation. Peasants who fail to meet commonly expected standards of life due to these problems are excluded and left to their sorry fates. Despite all these negative aspects, peasants in the stories of Sabahattin Ali are also observed to be affectionate, honorable, philosophical and naive characters who are actually perfectly intelligent.

The image of the peasant in his stories can be generally expressed as one of individuals who have struggled against harsh living conditions and a cruel nature for many years with limited opportunities and who have thus remained underdeveloped, poor and worthless. Peasants are victimized by a political system that considers them human beings only at the time of elections. In the stories, the peasants and intelligentsia are separated from each other through clear and explicit lines. In his stories, the intelligentsia actually represent the embodiment of ideology. Sabahattin Ali criticizes not only the corrupt intelligentsia, but also the dominant powers and the ideology. He portrays peasants and intelligentsia as non-idealized characters who can easily be related to those found within society. The author bases his fictional stories around an unquestionable conflict, which may relate to a Marxist dialectics. His stories can be considered to be partaking in a kind of in reflection aesthetics' as they reflect the problems of society as if in a mirror, as well as adhering to a "Marxist" or socialist esthetics as they seem intended to privilege the oppressed and object to the tyrant.

Class conflicts, such as peasants versus the intelligentsia and employee versus employer, that are shaped within a social order according to the conditions of the period, cannot be considered independently from economic conditions. In this context, Sabahattin Ali can be read within the scope of the relationships between the "infrastructure" (oppressed/producing class, labour, community) and the superstructure' (dominant powers, bureaucrats/intelligentsia) within the Marxist aesthetics that was developed as part of so-called "reflection theory".

\section{Study Objective}

Persons suggests that humans have viewed each other in social hierarchies for centuries and considers the following primary features of these:

"Affinity relationships, authority and power, possessions or wealth, personal qualifications, achievements. In every era, the decision concerning which one of these qualities would be prioritized and who would be placed in certain social positions depends on the dominant value system of that era. For instance, feudal community attaches importance to innate qualities of humans. Capitalist community regards the economic power. Socialist systems, on the other hand, (ideally) evaluate everyone according to how they perform the role required by their position. Nevertheless, as none of the communities are purely involved in these three types, hierarchy includes all five aforementioned elements in every community" (Person, 1991).

It is appropriate to use the perspective of "Marxist literate aesthetics", which are grounded on Karl Marx's theory of economically-based class differences, to analyze the stories of Sabahattin Ali, a writer who successfully portrays the communication and interaction between these social classes.

In his stories, peasants and the intelligentsia are separated from each other along clear lines. In the stories, the intelligentsia also represent the prevailing ideology. Sabahattin Ali criticizes not only the corrupt intelligentsia, but also the dominant powers and the ideology.

In Ali's fiction, peasants and intelligentsia are portrayed as idealized characters who could, nevertheless, easily be encountered in society. The author focuses his fictional stories around an unquestioned conflict. His stories seem to have affinities with theories of "reflection aesthetics", since they reflect social problems, and "Marxist/socialist aesthetics", since they support the oppressed and take a stand against tyrants.

Class conflicts, such as those between the peasants and the intelligentsia, and employees and employers, that are shaped within the social order according to the historical demands the time cannot be considered independently from education. In this context, it is recommended that the stories of Sabahattin Ali be read within the scope of the relationship between the "infrastructure" (the oppressed/producing class, labour, the community) and the "superstructure" (the dominant powers, bureaucrats/intelligentsia) within Marxist aesthetics that was developed as part of "reflection theory".

The primary objective of this study is to teach about the historical class conflicts found within the social order of the time and the personal and social harm caused by these conflicts to groups of schoolchildren and middle to old-aged people using the stories of Sabahattin Ali. Reading about past events and phenomena in literary works, 
such as stories, novels, poems, will increase the culture of communication, interaction and cooperation between social classes and consequently enable communities to build their future on solid bases.

\section{Study Method}

This qualitative study was designed following the screening model. As this is qualitative research, document review was used as a data collection tool since it was considered appropriate with regard to the statement of the problem. In this context, the stories of Sabahattin Ali, which depict many events that have fundamentally challenged society, were screened and descriptive analyses were conducted via the acquired findings. Documents are among the most important sources of information in qualitative studies. Document reviews comprise the analysis of written materials that contain information about the phenomenon to be investigated (Yildirim \& Simsek, 2008, p. 187).

\section{The Conflict between Peasants and the Intelligentsia in the Stories of Sabahattin Ali}

\subsection{Peasants}

\subsubsection{Affectionate Peasants}

In "The Mill" (1929), one of Ali's first stories, an old gypsy tells how peasants like and help them despite the little robberies they carry out in villages they travel through:

"You know what, my namesake? Even though these peasants complain about us for stealing their chickens and yeanlings, they still like us".

"They picked almost a kilogram of wheat altogether and gave it to Atmaca. And the miller added two pots of yoghurt".

"Taking heart from this warm welcome, we have set up our tents under olive trees that are not so far from here" (Ali, 1997a, p. 16).

Within the context of a didactic Marxist literary aesthetics, peasants, employees and oppressed people are believed to tend to experience the worst things in a literary work. Despite this negative view, the tradition of Marxist literature tries to emphasize the virtuous aspects of oppressed and despised people and establish a two-point dialectics. Ali constantly emphasizes the untouched, uncorrupt humanity of peasants, as well as their pure and innocent characters. Even though their advantages are few and their products, which are obtained through punishing work under harsh conditions, are stolen by gypsies, the peasants are still able to like them and maintain a forgiving and embracing attitude. The poverty and life struggles of the peasants under bad conditions do not seem to have destroyed their humanity. On the contrary, all these negative factors promote their humanity.

\subsubsection{Abused Peasants}

In majority of Ali's stories, the reason that villages and peasants remain underdeveloped is associated with the negative and erroneous policies of those in political power. The author thinks that villages lack sufficient social services (roads, water, electricity), which is the result of the negative attitude of those in political power towards villages.

"A Forest Story" portrays the tragedy of peasants deprived of governmental services such as education and health and welfare services, who render military service for their nation but are never legitimized or legally recognized by institutions except through the collection of taxes. An elderly peasant expresses this in the story in the following short and wise statement:

"Young man, we are peasants. We are not able to understand much. The company told us that they would work these forests with the best system. They also told us how we were failing, which was probably true. But tell me, is it right to leave us helpless by taking advantage of our failures in this work? They have used our ignorance and helplessness as an excuse for lining their purses. They knew we would not be able to compete with them. They put us through the mill without mercy".

"Everything, I mean everything had finished back then... None of us had the strength to smile... Even the village was no more the village we had known in our whole life. We, elders had a difficulty in recognizing it. A stranger was selling food and drinks to company workers in a small hut by the side of the borough road. And they were strolling in the streets of the village collapsing" (Ali, 1997a, pp. 85-86).

This story contains representatives of power, authority (oppressor) versus the powerless (oppressed), which could be considered the major themes in the context of Marxist literary aesthetics. This quotation also shows the dramatic collapse of the lives of peasants whose ignorance and purity are abused, as well as making a severe 
complaint: It is the complaint of peasants who are abused by a company that is managed by literate people who consider themselves to be the intelligentsia exploiting the peasants' deficiency and ignorance. The company has begun to use possibilities of the government support it receives for its own benefit and ruins peasants, who feel, due to their poverty, the difficulty of life in their bones.

\subsubsection{The Revenge of Peasants on Speech-Loving Intelligentsia}

The story titled "A Conference" draws attention to the deep and silent struggle between the intelligentsia and peasants: a crowd with golf pants, flat caps, black glasses and cameras arrives in one of the villages near the city for the purpose of opening the new school. They consist of "educational administrators, inspectors, significant men of the city and village supporters". This group of city-dwellers/intelligentsia, which also includes a man who had studied socialist villages in Paraguay, gives speeches on a number of issues such as spand "cooperatives". However, the peasants understand nothing about these speeches. The city-dwellers/intelligentsia ask, "Why are they so unaware of and insensitive to everything?", whereas the peasants think that these literate men "ask them such incoherent questions" (Ali, 1997b, p. 83). The intelligentsia intend to relay their theoretical knowledge to the peasants to who they barely know are and enlighten them with this. One of the economists in the group of city-dwellers says: "It would be useful this is the chance, and tries to speak to the peasants about cooperatives. The peasants gather. The conference starts. The economist gives a good speech using strange language without considering the nature and educational level of peasants. When the speech is over, the peasants remember nothing, as if they had woken up from a deep sleep. However, they reward their guest by saying "You are very right! We all got it!" (Ali, 1997b, p. 84). When the city-dwellers finish their speech and leave, an old teacher who is staying with peasants says that even he had not understood anything. The peasants take courage from that confession and one of them says, "In point of fact, we didn't understand anything, either, but what can we do? We just listened". As if scolding his students, the teacher asks, "So why didn't you say this? The poor man asked many times". Wearing a serious expression as if trying to restrain laughter, the peasant says, "Oh, sir! He would have said those things over and over if we had told him that we hadn't understood" (Ali, 1997b, pp. 84-85).

In this story, written in 1941, peasants apparently begin to understand that the works and speeches targeting them exist only as slogans and they will do no good. Thus, the peasants cannot bear to listen to that nonsense "over and over" and, in this way, they take a secret revenge over those strange speech-lovers with their sincere attitudes by just "not understanding them" (Korkmaz, 1997, p. 140).

Sabahattin Ali's works are generally fictionalized accounts of the struggle between two diametrically opposed social groups (the peasants and intelligentsia). This struggle generally results in the revenge of the oppressed/despised. Portraying the "revenge" taken by the oppressed over the oppressor (the peasants against the intelligentsia) delicately/masterfully within the context of Marxist literary aesthetics, Ali seems to prove that peasants can never be figures of hate. What may be called "revenger peasants" in his works are individuals with a mental agility who have suffered greatly and who provoke sympathy. Peasants with such abilities do not forgive mistakes and they take revenge according to their own methods.

\subsection{The Intelligentsia}

\subsubsection{Materialistic Intelligentsia}

In his story, "A Scandal", Sabahattin Ali tries to depict a corrupt intelligentsia character in the figure of a teacher in a Central Anatolian city:

"Men had probably become engineers, doctors, lawyers or teachers for the purpose of earning money, dressing well and having a beautiful wife rather than meeting their needs for ideas. In other words, they were using their mind, the most noble part of their being, as a butler to their stomach and genitals. The pure and non-materialistic mind had become an unnecessary thing for that mentality which only considered their bread and butter, had completely forgotten their actual task and ability to think and had become a simple machine. The role of the mind was no greater than that of an appendix" (Ali, 1997a, p. 226).

In the aforementioned paragraph, the author describes the condition of intelligentsia in that period with the help of vivid images and takes the readers on a journey back in time. The intellectual characters mentioned in the story are individuals who have benefitted from social conditions, who avoid interfering and who manifest stereotypical opinions. The author tries to relay this impression to readers via the following statement from the story:

"They had particular and memorized opinions about the world, the nation and the government and paid maximum attention to avoid interfering" (Ali, 1997a, p. 226). 
Using a teacher to represent uncorrupt intelligentsia, the author continues the story with a conflict between the so-called "patriots". In a meeting, the peasants begin to speak about their problems. A character named Vasaf Bey who has designs on becoming a member of parliament says: "After all, peasants are the masters of nation" (Ali, 1997a, p. 226). Hearing that statement, the teacher immediately interrupts him and says: "I will tell you one thing: Masters are those who employ and dominate others, not those who work day and night and end up having nothing at all" (Ali, 1997a, p. 226). These words of the teacher create a shock in the so-called intelligentsia and, through them, Ali gives his readers the task of discerning masters from slaves.

Speaking on behalf of the author, then, the teacher compares city and village to prove Vasaf Bey to be wrong and suggests that while city receives benefits from the return of their taxes, the village is in a totally different condition: "Peasants ... are obliged to construct their roads. Their streets are darker than their destiny and among a hundred villages, not even one has a school. The gendarme goes to them to collect taxes rather than to maintain public order" (Ali, 1997a, p. 227). These statements signify that peasants continuously give but receive nothing in return.

\subsubsection{Corrupt Intelligentsia}

In "The Dog", Ali compares the corrupt intelligentsia with pure peasants and points to the alienation between these two types of characters under the conditions of that period. A young man who had studied engineering in the United States stops his car while driving to Konya when his fiancee says, "Honey, I have never seen peasants and would like to see them" (Ali, 1997a, p. 136) and the young man then goes to talk to a shepherd. They have quite an interesting dialogue, but the shepherd understands none of his words, because the literate city-dwellers speak a different language and know nothing about his life conditions. The finance has probably seen the words "shepherd" in a few stories and she probably hopes to impress her friends in the city by talking to a strange-looking shepherd from a village. During their conversation, the engineer starts to talk about "supported villages" and humanity and says: "Look how interested we are in you. You are our peasant brother. We are one of you, too" (Ali, 1997a, p. 276), which causes the shepherd to suppose that they are actually from the village:

“The shepherd asked curiously: 'Do I know your family?' The engineer did not understand at first” (Ali, 1997a, p. 276).

This story narrates the encounter of two different people who cannot communicate and the conflict of the values they represent.

The engineer is an educationally and morally corrupt character. He is far removed from the general public. He is engaged to the daughter of a rich and powerful man who had also studied in the United States. This engagement provides him many opportunities that he does not deserve. He becomes employed at a bank with a high salary, though he is not professionally qualified for that position (Korkmaz, 1997, p. 137). He is thus the living embodiment of a corrupt mentality. Instead of offering consistent ways for the shepherd to abolish his poor living conditions, he advises the shepherd, "You should find a landlord's daughter or something", demonstrating that one of his principles is using people like himself, and especially his spouse, as a stepping stone to a prosperous life.

Boasting about having a top make of car, a monthly income of four to five hundred lira, a rich finance and a fancy house, the engineer represents the corrupt intelligentsia who are strangers to their own society and who go abroad to study. On the other hand, the shepherd barely survives, has a yearly income of a maximum of twelve lira and has not received a piaster from his employer for two years. His dreams of going to city and earning money have been shattered many times due to the negative activities of others. The shepherd is also conscious of his responsibilities, and has to look after his aged mother.

In the story, the author tries to describe the living conditions of peasants in that period through the figure of the shepherd, and the corrupt, isolated intelligentsia through the character of the engineer. There is a great gap between the protagonists of the story, the engineer and the shepherd. While the engineer has a monthly income of four to five hundred lira, the shepherd earns twelve lira a year and he has not even received it from his employer for two years. The engineers years from elve lira the shepherd. Living a secret aspect of the conflict between peasants and the intelligentsia.

\subsubsection{Idealist Intelligentsia}

Sabahattin Ali had taught in many villages of Anatolia, taken a close interest in the problems of villages and peasants and frequently touched upon villages and their problems in his stories. In his story "The Asphalt Road", Ali tries to make readers feel the demands of being a member of the idealist intelligentsia through the narrative of a village teacher. 
The teacher enters the world of peasants on the first day he goes to a village, becomes intimate with them and even makes efforts to rebuild the village road, which is the greatest problem in the village. He is regarded as a member of the idealist intelligentsia as he has adopted this matter and taken it on as his own problem. The teacher enters the world of peasants over a short period and adopts their problems as his own. Ali makes the idealized teacher character in the story speak as follows:

"It hasn't teacher cha follows character in e together and arrange the lessons. The peasants can easily understand those who speak in their language. I haven assents can world of peasants oes tow ever, I have been dealing with that road matter for month" (Ali, 1997b, p. 10).

The intelligent village teacher in the story intends to bring liveliness and vivacity to the peasants and enlighten them, as is required by his intelligentsia status. He reads the peasants the Ottoman Constitution and enables them to learn their rights:

"A peasant that had some business at cadastre had submitted a petition and then demanded a response. When the officers pretended they had no idea about the response, he had said: You will simply give me a response! You have to! There is a law! They inquired, investigated and when they understood that I had showed him how, they complained to the director of education" (Ali, 1997b, p. 11).

As the author puts it, peasants, who use their own internal "barometer", trust the teacher director of education understand the fact that their need for a road is used as a political bargaining-tool by administrative bureaucrats drives the peasants mad and causes them discomfort. They associate this disappointment with the teacher and end up siding against him. The teacher, who starts out with good intentions, in the end encounters a bureaucratic obstacle. He becomes the only offender in the eyes of peasants, who lack broad thinking and the ability to seeing the inside of affairs, because it was him who had encouraged the peasants to claim their rights.

\section{Conclusion}

Emerging after the October Revolution that occurred in Russia in 1917, Marxist literary aesthetics is based on a Marxist world-view and prioritizes that in characters it creates. Many "socialist realist" authors/poets write within the context of Marxist literary aesthetics, although their influence is much diminished today. Even though characters that are created in literary works expressly for disseminating ideologies are generally designed in line with their authors' thoughts, dominated by them and are far from realistic, we can observe conflicts (such as that between the peasants and intelligentsia), which are in accord with the Soviet era literary aesthetics while reading the adventures of Ali's protagonists.

The stories of Sabahattin Ali generally contain people living in prosperity on the one hand and the poor, in need of bread, on the other. As the poor are always oppressed and not able to receive education, they feel unhappy and despised. The author always supports the oppressed while expressing the differences between the poor and rich, the public and the intelligentsia (Karaca, 1997).

Ali uses these oppositions while selecting the heroes of his stories. He gives extreme examples to show the gap between the two groups and explicitly supports the oppressed while delineating the differences between the peasants and the intelligentsia.

"Considering Sabahattin Ali's stories as a whole, it can be observed that the peasants and intelligentsia remain timid, closed-off and strangers for each other" (Korkmaz, 1997, p. 140). In stories that mirror the details of that period: "The intelligentsia has not yet returned to their country from their colleges" (Korkmaz, 1997, p. 140). They sit in their pleasant surroundings and ivory towers and learn only the useless parts of life from books. They go to school and university to fulfil their physical needs alone and lack intellectual depth. On top of all these deficiencies, they have a tendency to express their opinions on every subject, which makes them seem even more ignorant than the truly ignorant.

In Sabahattin Al, the intelligentsia excludes idealist people with "an intellectual depth", like the teacher in the story "A Scandal", who is defamed by society for "committing the offense of seeing in the country of blind" and tries to isolate himself from society. For Ali, then, the peasants are destined to remain poor, excluded by the intelligentsia and left to their ill fortune. The peasants do not have the means to understand the intelligentsia, while the intelligentsia does not make the effort to understand peasants. Whenever peasants are mentioned, a simple solution is sought, one that can act as a drug, numbing their conscience. At that point, the statement "peasants are the masters of nation" simply meets that need. 
To sum up:

-There is an infinite gap between the intelligentsia and peasants, and the intelligentsia only pretends to support peasants.

- The intelligentsia is encountered as a class that is far from the problems of villages and peasants, unable to internalize the truth of villages and solve their problems.

- The intelligentsia approach the peasants only in theory rather than in practice.

-The intelligentsia despise the peasants.

-Although the intelligentsia is primarily required to seek solutions to public problems and produce projects to solve them, most of them only consider their stomachs and purses in their otherwise pleasant lives.

- The intelligentsia maintains certain, memorized opinions about the country, the nation and the government. Peasants, on the other hand, are not able to form ideas or shape policies as they are unaware of such concepts.

\section{References}

Alangu, T. (1965). Story and Novel after the Republic II 1930-1940. İstanbul.

Ali, S. (1997a). All Stories I. YKY, İstanbul.

Ali, S. (1997b). All Stories II. YKY, İstanbul.

Beneton, P. (1991). Social Classes (Hüsnü Dilli, Trans., 1st ed.). Communication Publications, İstanbul.

Çağbayır, Y. (2007). Ötüken Turkish Dictionary. Ötüken Nesriyat, İstanbul.

Cücenoglu, T. (2003). Sabahattin Ali. Mitos-Boyut Publications, İstanbul.

Enginün, İ. (2004). Republic Period Turkish Literature. Dergâh Publications, İstanbul.

Filiz, A., \& Atilla, Ö. (1986). Sabahattin Ali. De Publishing House, İstanbul.

Grigory, P. (1998). In the Country of White Lilies [Ali Haydar Bey, Trans.]. İstanbul.

Karaca, A. (1999). Social Issues on the Stories by Sabahattin Ali. Ankara.

Korkmaz, R. (1997). Sabahattin Ali "Human and Creation". YKY, İstanbul.

Kutlu, M. (1972). Sabahattin Ali. Dergâh Publications, İstanbul.

Moran, B. (1982). Phenomenon of Type and the Function of Type in Novel. İstanbul.

Moran, B. (2010). Literary Theories and Criticism. İletişim Publications, İstanbul.

Said, E. (1994). Intelligentsia [Tuncay Birkan, Trans.]. Ayrıntı Publications, İstanbul.

Türkdoğan, O. (2005). Anatomy of Intelligentsia in the Turkish Society. Timaş Publications, İstanbul.

Yiğit, M. (2011). Meaning and Context in Language. 1st International Conference on Foreign Language Teaching and Applied Linguistics (FLTAL'11) Sarajevo.

Yildirim, A., \& Simsek, H. (2008). Qualitative Research Methods in the Social Sciences. Ankara: Seçkin Publishing.

\section{Copyrights}

Copyright for this article is retained by the author, with first publication rights granted to the journal.

This is an open-access article distributed under the terms and conditions of the Creative Commons Attribution license (http://creativecommons.org/licenses/by/4.0/). 